\title{
Modern Teachers of Ars moriendi
}

\author{
Agnieszka Janiak $^{1}$ and Marcin Gierczyk ${ }^{2, * \mathbb{C}}$
}

1 Department of Media and Communication, University of Lower Silesia, 53-611 Wrocław, Poland; agnieszka.janiak@dsw.edu.pl

2 Faculty of Social Sciences, Institute of Pedagogy, University of Silesia in Katowice, 40-007 Katowice, Poland

* Correspondence: marcin.gierczyk@us.edu.pl

Citation: Janiak, Agnieszka, and Marcin Gierczyk. 2021. Modern Teachers of Ars moriendi. Religions 12: 695. https://doi.org/10.3390/ rel12090695

Academic Editors: Joanna Wojtkowiak and Brenda Mathijssen

Received: 13 June 2021

Accepted: 24 August 2021

Published: 30 August 2021

Publisher's Note: MDPI stays neutral with regard to jurisdictional claims in published maps and institutional affiliations.

Copyright: (c) 2021 by the authors. Licensee MDPI, Basel, Switzerland. This article is an open access article distributed under the terms and conditions of the Creative Commons Attribution (CC BY) license (https:// creativecommons.org/licenses/by/ $4.0 /)$.

\begin{abstract}
It is evident that a change is happening, a breakthrough, in perceptions of death; the next episode is being unveiled. After the stages Philippe Aries named death of the tame and then death of the wild, people today are finally experiencing the humanizing of death, which we call sharing death, whose influence is worth deep analysis. Our hypothesis is that today, Ars moriendi, meeting the needs of the dying, may be learned from the so-called death teachers, whose message is growing noticeably in society. This research shows a certain reversal of social roles that are worth noting and accepting. In the past, a priest was a guide and a teacher in the face of dying and death; today, he has the opportunity to learn Ars moriendi from contemporary teachers of dying, to imagine an empty chair standing by a dying person.
\end{abstract}

Keywords: priest; Ars moriendi; sharing death; death teacher

\section{Introduction}

One of religion's fundamental functions is the existential one. Each religious system facilitates facing existential dilemmas and provides tools to deal with the most incomprehensible and tragic aspects of human existence. J.M. Yinger, the American psychologist of religion, defines religion as "a system of beliefs and actions by which a community attempts to solve the most essential problems of human existence" (Yinger 1957; Piwowarski 1977, p. 14), among them dying, death and loss. In a classic work of thanatology, Vladimir Jankelevitch (1993) wrote that death has three aspects - three stages of initiation that successively reduce the distance between us and the mystery: (a) when we realize that everyone ("they") will die; (b) when we accompany someone's dying or experience the death of someone dear, we come to understand that "you" will die; (c) when I accept the fact that "I" will die.

Owing to our expectations of religion that are related to giving meaning to life and coping with our mortality, the status of a priest prevents him from stopping in front of this second curtain, forcing him to open it. A priest directly encounters illness, dying, death and grieving in his everyday life and work: by visiting hospitals or hospices, giving patients the sacraments, hearing confessions and facing such questions as "How could God have let it happen?", conducting funeral services, teaching in schools (in Poland), and dealing with grieving students who have suffered a friend's suicide, an accident, a teacher's death, etc. Always treated as a specialist on ultimate issues, a priest is obligated to make moral judgments in ethically blurred situations.

The reflections in this paper arise from ponderings over Christianity, but they have a universal dimension (Janiak 2019a). Despite the waning universal significance of religion, each has served important functions and duties toward the ill, the dying and the bereaving.

Research questions. The research questions of this paper are the following:

1. What are contemporary attitudes towards death in Western and European societies?

2. Who can teach us, today, what resources we need in order to get through a confrontation with death, and how? 
The findings on the subject of Ars moriendi teachers are situated within the Polish cultural context and the Catholic Church. A consequence of utilising an auto-ethnographic perspective is the use of male pronouns when referring to spiritual leaders-in the Catholic Church, these roles are only available to men. However, the concept of ars moriendi is universal, referring to more than Catholic texts from the Middle Ages.

\subsection{Priest's Role in the Dying Process}

The priest's connection with dying and death is extremely multidimensional and demanding. It is related to contact associated with regular visits to the hospital ward, to nursing institutions, or to homes of people who are bedridden, old or dying. Furthermore, it also implies contact with mourners in the parish office; participation in funerals; confession of desperate orphans and potential suicides; religion lessons at a school where a parent, teacher or a colleague has committed suicide, or has fallen victim of an accident or an incurable disease. Each environment expects that the priest will express a clear, well-argued sentence about such ethical dilemmas as euthanasia, abortion and transplantation. These contacts are very demanding and emotionally burdensome. The priest will be able to meet the expectations when he knows how and will be aware how importance his presence and skilful accompaniment are.

A priest who wants to immerse himself or is simply thrown into the reality of an ill person can do a lot not only for the patient, but also for the family and their environment: neighbors and acquaintances. The illness is a special time-a trial for bonds, revision, prioritization, intensive giving and taking. Often, it is the priest who is granted the ethical right to indicate duties toward the patient, to encourage expressions of solidarity, closeness, love and to common prayer.

The art of living with the ill, the dying and those in need of consolation and compassion is, therefore, a kind of mission or mission of religion and its churches, it determines the charism of many religious orders (e.g., the Brothers Hospitallers of Saint John of God or the Camillians) and is clearly inscribed in the history of, e.g., the Christian Church. Historical data confirms the fact that the church is a precursor of activities for people in need; it started organized health care by creating hospitals, hospices and care centers for the sick and orphans. Councils and synods, e.g., the Cartagena Council (309 A.D.) or the Synod in Tours (567 A.D.) managed the construction of such centers at the churches where people in need, the ill and the widowed will be welcomed and looked after. Around 370 A.D., Saint Basil, bishop of Caesarea Mazaca in Cappadocia in what is now Turkey, created an institution called Basiliada that was a real care team with a clinic, a refugee unit, a hospital and a shelter for lepers. At the same time, various types of hospitals were created: "xenodochio (sheltering pilgrims, wanderers and refugees), nosocomio (a hospital), orfanotrofio (an orphanage), gerontocomio (a shelter for the elderly). [ . . . ] The church must help the ill and try to give meaning to their suffering ('Is anyone among you ill?' Jas 5:14). The Church should contribute to creating favorable conditions for life; it should stigmatize every attempt to kill life, and prioritize the values of understanding, listening, service and love", as the first bishop of the Brothers Hospitallers of Saint John of God, Jose L. Redrado (2010, pp. 84-85) emphasizez.

Accompanying those confronting death has a long, beautiful, significant and inspiring tradition in the Roman Catholic Church. Recommendations for dealing with death were formulated in the so-called Ars moriendi, Ars bene moriendi, popular textbooks on "good dying", written in Latin, that appeared at the beginning of the 15th century. They had the dimension of practical manuals of appropriate behavior toward the ill, the dying, mourners and clergymen. They provided "a kind of simplified" catechism for the dying and the people accompanying them and, at the same time, a simple instruction on what and when to do and to say (Machinek 2009, p. 81).

Machinek, who quite often reflects on contemporary duties and the shape of the service to the ill and the dying, points out: "It is obvious that modern times cannot directly reach for late medieval treatises which were developed on the bases of the mentality of 
that era, as well as the challenges of those times" (Machinek 2003, p. 249). Nevertheless, he legitimately sees inspiration flowing from Ars moriendi to the present in three areas, if we look at the art of dying: the art of living, the art of communing with God (deriving from concern for eternal salvation and revision of the attitude toward the world in the face of death), and practical help for the dying and their loved ones (Machinek 2003, p. 249).

\subsection{Understanding Ars moriendi}

Thanatologists notice several clearly distinguished stages in the history of understanding and responding to death.

\subsubsection{Attitude of Acceptance-Living with Death}

From antiquity to the mid-19th century, death was treated simply as a natural and necessary element of life, accepted as part of everyday life; the general attitude toward death was determined by the awareness that everyone would die. What is important is that death was considered an existential phenomenon with its own ontology; it was treated as an independent liminal event, very important, worthy of being experienced consciously, and not the last failed, shameful stage of disease. Death was a social act that hurt the entire community; it was a public, open and visible matter, included in the framework of the socializing cultural ritual that set the framework for encounters with death, approached not without fear, but without panic - a tamed death (according to Ph. Aries). Religion and tradition helped in the "survival" of death. This time could be considered an era of faith, with theology as the dominant discourse, focusing its attention on death as an eschatological and social event.

People "lived with death", adopting an accepting and religious attitude, seeing death as a spiritual transition and a key moment often decisive in attaining eternal life. The priest was always called to the ill and the dying: he was a person with the highest social authority, whose presence and administration of the Last Rites could ensure salvation. Prayer was the strategy adopted to deal with the threat of death, and the prospect of a future meeting in heaven was the comfort for mourners (and motivation to achieve salvation). The priest was an undisputed authority for the dying and their families, and he himself felt confident in this role not only because of social recognition of it but also, thanks to real, practical help concerning what and how to do in the face of dying, the help provided by Ars moriendi manuals.

\subsubsection{Attitude of Rejection-Negation, Tabboisation, Denial, Fighting and Escape}

This attitude toward mortality changed in the mid-19th century through individualization, secularization and the introduction of life-support machines. The process of individualization liberated people from family and tribal relationships, led to social atomization, and contributed to awareness of the senselessness of the world and human existence in it. It became the goal to "be one's true self" instead of participating in the community and the rituals that gave it cohesion and durability. Social rituals to tame death - the vigil at the deathbed and then with the corpse; the funeral, wake and manifestation of mourning-provided a pattern of conduct in the face of death and pointed to the eschatological dimension of human existence. Without faith in God and comforting rituals, death became devoid of meaning, function, place and value, and nowadays we have managed to cope with its terror by making death absent, a social taboo. Secularization awakened a fear of the reality of non-existence or death-nothingness, while resuscitation techniques began the process of medicine's appropriation of death. In the face of death, professional medical knowledge was given authority. Death is identified with illness and has ceased to exist in social consciousness as an element of nature with its own existence. It has lost its metaphysical, sacred significance, becoming an exclusively medical event-an illness that could not be cured, the doctor's failure. This understanding of death was called, in contrast to tamed death, feral death (Aries 1974). It is death repressed from individual and social consciousness. As a result of this denial, "it goes feral" and fills 
people with increasing fear and terror. There is a conspiracy of silence. Death becomes a taboo, a new category of obscenity. It is hidden; its reality is denied, as well as its existence. This widespread conspiracy of silence has been sanctioned by the functioning of hospital ideology.

The new era of biomedicne, which lasted until the mid-1980s, kept death under control. Death no longer constituted the liberation of the soul, but a failure of the body (Conrad and Schneider 1992). Ensuring health was solely the experts' job. A man who is not an expert does not have the right to his own death (or birth) (Woodward and Woodward 2020); he must hand it over to specialists (among whom there is no place for a priest) and institutions (Curtin 2019). Being born and dying in hospitals has eliminated the idea of home from our culture. Because people no longer die at home, but in hospitals or hospices, the dying - previously members of the community-become dying patients of the hospital (Gawande 2014). However, they are not the protagonists of this final act; the doctors are, and they are the ones who own all the knowledge on illness and dying, which they may or may not (or not fully) share with the patient. In the face of death, the doctor, not the priest, is given authority (Walter 1996b, 2017). Mourners, often deprived of the opportunity to say goodbye to their loved ones (who were supposed to recover, in their minds) as well as a socially accepted and supported right to mourning, are offered sedatives and the advice to see a psychologist. Mourning, therefore, is considered a disease that should be cured by experts and isolated so that the sadness does not disturb other people.

\subsubsection{Attitude of Companionship-Raising Awareness; Living with the Dying}

In the history of changes in attitudes related to death, another breakthrough is taking place as humanity has entered the next stage contributed by the publication of "On Death and Dying", by Dr. Elisabeth Kübler-Ross (1969), as well as Cicely Saunders's opening of the model hospice of St. Christopher in London in 1967 and her intense activity to popularize the hospice movement. "In the years immediately after World War II, good hospice care primarily meant concentration in the spiritual and psychological area. The initiator of this movement was Dame Cicely Saunders. In practice, this meant being with the patient, listening to them, understanding and respecting their dignity and meeting existential needs. With the increasing involvement and participation of medical staff, it turned out that the medical aspect of hospice care needed to be changed" (de WaldenGałuszko 2011, pp. 197-201). The emergence and increase of hospices as places where help in dying is provided without unnecessary suffering (physical, spiritual and mental) overturned the taboo of dying and restored death to its due place in social space.

Since the 1970s in the United States and the mid-1980s in Europe, appeals and initiatives have advocated restoring the repressed awareness of death and the right to face death in all its significance. The postulate of the so-called ethics of care was formulated, in which the doctor's main ethical concern as not to fight ruthlessly for life, but to care for the dying. A new specialty emerged - the doctor of terminal care and then palliative medicine-and the conspiracy of silence was broken. The doctor is now obliged to inform the patient about a lethal prognosis (Article 17 of the Polish Code of Medical Ethics). At that same time, a scientific subdiscipline called death anthropology or humanistic thanatology was established in France and United Kingdom.

Dying, however, has not regained its public dimension, but has become a kind of personal death (Walter 1996b) that loved ones, in the age of Covid, even allow. What becomes public and generally available is the reflection on the intimacy of death, and on the importance to the dying of individual accompaniment; an indication of effective social communication tools in death; and the promotion of courage in undertaking this existentially significant act of intimate presence and being open to other people.

The answers that contemporary culture gives to the difficult question of how to die, we can concisely sum up in three phrases:

1. At home, with a priest and amongst relations.

2. In a hospital, alone, often uncoscious. 
3. Where and when you want, I'll take care of it.

It's important to point out that these three approaches are not isolated events. Although their prevalence is arranged in the order of succession (each of them dominates at a certain time), the emergence and dissemination of a specific attitude does not assume the disappearance of the attitudes preceding it. One should fully bear in mind, remembering about Weber's ideal types, that these attitudes are co-occurring today.

\section{Materials and Methods}

\subsection{Purpose of the Study}

This paper pursues two goals: the first is to encourage clergy members and strengthen them as teachers of dying. The second one is to reconstruct the figure of a modern teacher of dying. The humanizing of death movement, whose history goes back 70 years, has its teachers whose actions and social significance are promoted and strengthened by the media. Theoretical inspirations for reconstructing the figure of the contemporary teachers of death are found in the theses related to compassion, internal development and authority, especially among concepts of Martha Nussbaum, Margaret Archer and Carl Rogers.

\subsection{Theoretical Framework}

The concepts presented in the paper are based on observations, reflections and the textual analysis of the content of statements from those we call dying teachers. The figure of the teacher of dying first came to mind from our own experience. Our friend Kasia unexpectedly learned on the 27th of December 2016 that she was incurably and terminally ill, and painkillers were all that modern medicine could offer her. Kasia died on 20th of April; she was 49. She died at home, conscious, prepared, holding her children's hands, in the presence of all those closest to her. We had the honor and privilege of constantly accompanying Kasia during her illness, dying and the moment of her death.

Kasia was very active; she also practiced nordic walking. Every day we went to her, even for $15 \mathrm{~min}$ - to the hospital or her home - with the so-called stationary nordic walking. I brought in a thermos for special tea and lovely cups; we had "picnics on the quilt". We treated the therapy with a laugh. We dared our friends and neighbors-62 people- to go to Kasia for a prayer of constant hours every evening. We organised volunteers to do shopping and healthful cooking, make short daily visits and take Kasia to the doctor comfortably by car. Kasia let us into her privacy; she opened her home and then allowed us into her intimacy-helplessness and tearing off the dignity of the disease. We were aware that we were attending something great, the most important stage of life.

We attempted to make some sense of our experiences and to understand the question that life itself had presented us-how it was possible (and thanks to whom) that we were able to accompany Kasia during her journey towards death; an objective tragedy became one of the most cultured and beautiful existential experiences we had ever had. The autoethnographic approach led us to treat this moment as a call to action, something in need of understanding.

So, the conceptual starting point was our experience of confronting our friend's death, wanting to come to terms with its purpose: finding understanding, control and utilization from something that feels senseless. This biographical imperative led to the adoption of an autoethnographic research strategy. Autoethnography is a method used in qualitative research (Ellis 2004). Autoethnography is a research strategy (also widely regarded as a paradigm or, in turn, narrowly as a research technique) that finds and marks the person's place in the space of scientific exploration (Richardson 2000). Autoethnography is the opposite of directed theory, or a method of testing hypotheses based on positivist epistemology. In this sense, Laura Ellingson and Carolyn Ellis see autoethnography as a project of social constructivism that rejects the deeply entrenched dichotomy between researcher and subject, objectivism and subjectivism, process and result, self and others, art and science, and the personal and political (Ellingson and Ellis 2008).

Our autoethnographic process involved a few stages: 
1. Reflecting upon our own experiences.

2. Comparing these experiences to those of others, leading studies in the USA from 2012 on the topic of sensitive communications.

3. We selected a cultural and societal frame-described by us as sharing death.

4. In the end, we selected a societal application-a useful change that could benefit those confronting death, able to meet it face to face.

\subsection{Methodology}

Using the analytical autoethnography, we would like to point out (without analyzing and discussing) the situational factors, personality patterns and social competence needed in the three stages of the process of becoming a death teacher: experience, reflection, involvement. They have been constructed on the bases of books, personal testimonies, blogs and vlogs, interviews and media talks of those we treat as modern death teachers. The general reflection on the change in attitudes toward dying, death and mourning, as well as the expectations toward clergymen presented in the introduction, has been constructed largely based on research the first author has been conducting in Poland and USA. This work represents an analytical autoethnography in which it is assumed that the researcher conducts a reflective analysis of the group or social system of which he is a member. This type of autoethnography is best geared towards understanding broader social phenomena through theory (Anderson 2006); in the context of this study, information from the dying, as well as death teachers was paramount. We realise, like other researchers (e.g., Kacperczyk 2014; Kafar 2010), that there are many possible paths to acquiring knowledge, many paths to reach "understanding" - such as through art, shared experiences, poetry, film or working together.

\section{Results}

\subsection{Stage of Humanization of Death}

Paying attention to the stage of humanization of death, Walter (1992) gives credit to contemporary psychologists in this regard. Speaking of the secularization of the approach toward death and mourning, he uses an eye-catching, concise formula-from theology to psychology (Kubiak 2014, p. 30)—and advocates eliminating the eschatological dimension of death in the modern approach, replacing the theological reference with psychological one (Curtin 2019; Woodward and Woodward 2020). This thesis, however, seems too radical and unverified by the practice of social behavior in the face of death.

In Poland, a priest is asked far more often than a psychologist to accompany the dying - not because of tradition, but rather because the argument is that, at the end of life, greater peace of mind may be obtained not by psychotherapy which mainly proposes an analysis and expression of emotions in the course of a long-term therapeutic process, but thanks to religion, which helps forgive and accept one's fate. Kilpatrick, a psychologist of religion, points out:

[ ... ] a real test for a given philosophy or way of life is not whether they can alleviate the pain, but what they say about pain they cannot alleviate. This is where, I believe, psychotherapy turns out to be insufficient, and we find support in Christianity because from the point of view of psychology suffering has no meaning, while from the Christian point of view it means a lot (Kilpatrick [1983] 1997, p. 205).

\subsection{Religion and Psychology}

The relationship between religion and psychology has been subject to numerous discussions. To achieve the art of co-existence with the dying and their families, it seems a complementary attitude works much better than a confrontational one. Psychology focuses on human emotional well-being, theology on the transcendental sphere. It is easier, then, to be effective in religious service when this emotional well-being is taken care of in advance. A priest is not equivalent to a psychotherapist, but his knowledge of emotional states and 
attitudes of suffering people will help him predict reactions, significantly facilitating or even enabling a satisfying relationship with the ill and their loved ones. Analogously, a psychologist or psychotherapist can help suffering people only when, apart from their experiences, emotions and beliefs, they take into account their spiritual life, faith, hierarchy of values and dilemmas of conscience.

In the spheres of sociological, psychological and healthcare researach, spirituality as a concept has been receiving increased attention over the past few decades. Two important factors in maintaining health and longevity are spirituality and religious coping. They also become important during the recovery process (such as from traumatic stress), during chronic and terminal illnesses, and during bereavement (Campesino and Schwartz 2006). In the Catholic faith, "spirituality" is used to mean living out the Christian way of life with fervor; though it is easy to see that not everyone in the same faith follows the same path.

There have been a variety of definitions used to characterise and express the boundaries of spirituality, including "the best of that which is human", seeking answers to existential questions, and the transcendent human dimension (Zinnbauer and Pargament 2005). True spirituality must be understood as something more than moralism or humanism, rather its main purpose is to help people develop a meaningful relationship with God (O'donnell 1982). Further research has shown to psychologists and other social scientists the importance and potential implications of spirituality for human functioning (Pargament and Mahoney 2012).

Father Lucjan Szczepaniak, a chaplain at University Children's Hospital in Kraków, emphasized some the phenomenon of depriving a priest of a particular role:

It is [ ... ] tempting to reduce the mission of a priest bringing God to the ill to the role of a sad comforter lost among people overwhelmed by suffering. A man seen as burdened by God with the encumbrance of his misunderstood priesthood. Embarrassed the cruel accusation of God whom he must continuously defend. Someone who has stopped confessing and giving Christ's body to the ill, but now only hears informal confessions and holds people's hands, if he has not abandoned his duties yet (Szczepaniak 2010, p. 73).

It is worth emphasizing a certain paradox. The clergyman's social status has weakened nowadays; the priest's authority has been questioned and is no longer granted by virtue of tradition or a shared religious worldview. Meanwhile, the expectations of the ill, their families and caregivers, or, in the case of a hospital or hospice chaplain, by members of the staff and therapeutic team; visitors and all those ones confronted with someone's dying have expanded. Among the difficult and obvious tasks a priest is expected to perform is to be an insightful theologian prepared to answer all the "why" questions, able to recognize and satisfy the spiritual and religious needs of those under his care and, if necessary, to summon an Orthodox or Protestant clergymen "to meet the ill and their family together. There is no better example of ecumenism than a meeting with the Bible in hand by the patient's bed" (Szałata 2010, p. 37).

Clergymen are also expected to be able to diagnose and alleviate spiritual suffering, for families and medical staff members as well as the dying; to be sensitive to and report symptoms of physical pain and discomfort; to know the patient's rights and make sure that they are observed (e.g., a privacy screen during nursing activities), to counsel the patient; to relieve tension and improve communication between the dying, their family and staff members; to know how to comfort others and give them hope. Łuczak, researching expectations among doctors and nurses, also stresses that "the range of activities of a chaplain - a clergyman [ ... ] increases, as not only a 'soul' doctor, but also a confidant of the ill and their relatives, helpful in relieving somatic, mental and social suffering" (Euczak 2010, p. 16).

What behavior is expected from a priest? Listen and hearing messages, including the nonverbal (gestures, body positions); being kind, cheerful and smiling; being always available; taking his time; being calm and composed, understanding the patient's needs and being forgiving, not moralizing and judging; not acting automatically or falling into 
a routine; being discreet; making contact easily; being able to remain silent. Among the features of a hospital chaplain expected in Poland, Archbishop Grzegorz Rys emphasizes:

He must be there for every patient, but also respect the attitudes of non-religious people and atheists. His ministry should concern not only the patients themselves (preferably before their hospitalization) but also their families, as well as doctors, nurses and the entire hospital team. Therefore, he must be a competent theologian, but also a priest more predisposed to the role of a spiritual guide; a man of deep prayer, but also easily establishing contact and open. He is expected to be available and generous when it comes to time and energy; to administer the sacraments, but also to operate the hospital chapel and run a library for the patient [and then be ready to initiate or engage in conversations about read books [complemented by A.J.]. He is to be a witness of faith: it would be good if his first contact with the ill did not concern sacramental (or even religious) matters; for example, he should be interested in the patient's living situation (Rys 2010, p. 97).

This list of expectations shows how important it is to look for places or people who will teach others how to meet them-not to bend under them, but to take into account their versatility.

Not every priest is suited to being a hospice chaplain, to let contact with powerlessness, suffering, illness, death and despair fill his days, and often nights. Not everyone has what Father Krakowiak calls the Samaritan calling in his calling (Krakowiak and Janowicz 2012, p. 155). However, almost anyone can learn to accompany the dying "painlessly" when it is one of the aspects of his work - maybe even every day — but not the only one.

\subsection{Death Teachers}

People we consider to be contemporary death teachers or teachers of dying work publicly, using various media and accompany the dying, or are fatally ill themselves, to propagate and (re)definine Ars moriendi. They use the media and are supported by them-especially blogs and vlogs, public interviews and media talks. Among them are, Bronnie Ware (https:/ / bronnieware.com, accessed on 23 August 2021), Hunter 'Patch' Adams (https:/ / www.patchadams.org, accessed on 23 August 2021), Kathryn Mannix (@drkathrynmannix), Atul Gawande (http:/ / atulgawande.com, accessed on 23 August 2021), Agnieszka Kaluga (http:/ / www.zorkownia.pl, accessed on 23 August 2021).

They have become teachers of dying through intense professional contact with the dying and the mourning, on which they reflected and which they treated as an educational experience. Teachers of dying all take part in the helping profession, which can be defined as work in a constant, hands-on close contact with people, specifically those who require personal support in regard to existential questions and problems. Amongst their many responsibilities, it is important to point out that constant contact with the sick, dying and grieving requires a specific skillset.

They came to realize they had learned from the dying something significant, important and fundamental. Because of the importance of this experience and their conviction about its relevance, they became engaged in social education. Theoretical inspirations for the reconstruction of the contemporary death teachers are found in the theses related to contemporary categories of compassion, reflexiveness and authority, especially among these concepts:

- The philosophy of Martha Nussbaum (2016), who argues that contemporary democracies need compassionate citizens and that the basic purpose of humanistic education should be to educate citizens who can feel compassion. Compassion, understood as emotional disposition, allows making one person's experience an issue for another.

- The sociology of Margaret Archer (2000), who demonstrates in Being Human: The Problem of Agency that human beings are equipped with three emergent properties: reflection, emotion, and agency. Reflection is the most important, as it shapes individual 
and social life. It is humans' ability and duty to reflect on their emotions and ways to work effectively in the society.

- $\quad$ The pedagogy of Lech Witkowski (2011), whose monumental and erudite books Stories of authority towards culture and education and Challenges of authority in social practice and symbolic culture are devoted to pedagogical aspects of authority, understood as inspiration for in-depth reflection and mobilization to engage and inspire action.

There is a characteristic chain of alternation between educational and pedagogical roles: the dying (or mourner) becomes a teacher for the accompanying physician, caretaker or volunteer, and that student in turn becomes a teacher for the community, finding an audience for his message in lectures, interviews, books, articles and blogs. Kübler-Ross writes in her autobiography:

My dying patients taught me so many things other than-what's the feeling when you die. They gave me a lesson on what they could have done, what they should have done, and what they did not do until it was too late (... ). They looked back at their life and taught me everything that matters, but not in the context of dying ... of living (Kübler-Ross [1997] 2000, p. 172).

Kathryn Mannix (2018) refers to this as a reinterpretation of a world that seemed fully known: when working with confused people, we can distance ourselves and hear their expressions of worry and hope. This allows those who work with people whose plight may seem hopeless to take a step back and see that for a dying person, life is still purposeful and valuable. Around the bed of a dying person, we can meet people who discover each other and find strength in their mutual closeness. We can also witness the emerging community between strangers in a hospital or hospice, who are connected by deeply emotional experiences of the end of life.

Another factor worth mentioning is complementarity, or the bringing together of formal and informal supervisors. The priest, the chaplain and the psychologist not only complete the goals and duties set beforehand, and do it with full empathy, but also work "extra hours". The informal supervisors are treated as professional because of their experience. Ware is presented as a nurse, although formally she is not:

I went through two quick courses. The first one taught me how to clean my hands, the second one how to help the ill and the disabled to get up. That was pretty much all my training before I became a nurse. Giving me the role of Stella's supervisor, my boss advised me to not tell the family that I only had experience with one palliative patient. She believed in me. So did I (Ware 2016a, p. 37).

It is worth noting that death teacher is a kind of profession in which there must be multitasked engagements - even at the risk that the teachers will lose their own family life. Nevertheless, the death teacher's status is open, available to everyone but requiring some social skills. Apart from the biographical experience and the attitude of the reflective practitioner (the concept of D. Schon and C. Arygyris), the requirements for a death teacher also include personality patterns and social competence. The personality patterns often comprise such characteristics as independence; full autonomy (or even unconventionality) in thinking and acting; vigor and resistance to failure. Social competence necessary for the death teacher consists of empathy; accompaniment (and its derivative, patience); listening, communication with a touch and a smile.

Listening: Listening, we learned that all the dying patients knew they were dying. And it was not the question "Shall we tell them?" or "Do they know?" The only question we can ask ourselves is: "Can I listen to them" (Kübler-Ross [1997] 2000, p. 124).

Communication with a touch: During consultations, we would sit on the patients' beds, hold their hands, and we talked and talked for hours. We learned that there is not a dying person who would not need love, touch and talk. The dying patients did not like the safe distance the doctors are used to keeping in their presence (Kübler-Ross [1997] 2000, p. 124).

Smile: A smile, an axiological declaration of friendliness and, at the same time, a meeting of faces (Kaluga 2014). 
This personality pattern and social competence prove necessary in contact with the dying, but they also determine the carrying capacity of later social learning activities. What do the contemporary teachers of death teach us? What are their basic functions? The most obvious thing they teach is the ability and courage to accompany and the benefits of restoring the customs of mutual help.

\section{Discussion}

The movement to humanize death has its teachers and researchers. The death teachers are breaking the taboo, although they are still not making it a public matter. Even though death is not something embarrassing, to be overlooked and denied, there is still a notion of emphasizing its individuality and intimacy. Death, then, is still not entering the stage of public attention, but is rather becoming a kind of private death (Walter 1996a). The public stage, widely mentioned by the teachers of death, is the contemplation of the intimacy of death (Kubiak 2014, p. 43) writes about placing an individual experience in the central place.

Since 1991, Tony Walter, the founder of Centre of Death and Society at the University of Bath, has continuously emphasized the importance of this stage in humanizing death, giving credit to contemporary psychologists. The research about sensitive communication the first author has been doing since 2012 has aimed to verify the hypothesis that, arguably, more credit for the humanization of death from the psychology of mourning, "psychological expertise on grief", focused on minimizing the regret about living-brought and referred to "reflective practitioners", or teachers of death. Additionally, the first author's preliminary study points to our belief in their empirical knowledge and direct experience easily applied to social and individual practice.

In Poland, the priest is one of the professions that we expect to become a teacher of dying. One of, but not the only one who can and should become a teacher of dying, but is simply someone whom society expects to take on that role, knowing that priests have customarily fulfilled this role in the past. The contexts of religion often lead to priests being seen as the foremost experts on dying, seeing as how it is discussed in both religious texts and practices (across many religions); however, there are also secular groups and societies who have developed their own practices separate from religion, though they are not the focus of this text like: teachers, pedagogues, doctors, nurses, psychologists, social workers, court officers - in other words, those who we believe have felt the call to fulfill a certain profession-and society expects many things from them.

This research shows a certain reversal of social roles that are worth noting and accepting. In the past, a priest was a guide and a teacher in the face of dying and death; today he has the opportunity to become a student in modern schola mortis and is expected to take it. He has the opportunity to use an important media message-to learn Ars moriendi of contemporary teachers of dying, to imagine an empty chair standing by a dying person. That chair is waiting for him.

And although the social status of a clergyman has weakened-his authority questioned and no longer granted to him by tradition or a shared religious worldview-in the face of dying, the priest, using the message of contemporary teachers of dying, can and should ultimately become the teacher and companion of death. What we believe priest needs are preparation and courage: preparing and gaining confidence in contact with the ill and mourners; reducing stress resulting from his special job profile (frequent contact with illness, dying, death, mourning); recognizing and reworking emotions caused by this contact; equipping himself with methods and tools effective in communication with the ill, dying and mourners; replacing the paternalistic attitude with an attitude of partnership (resulting from the so-called care ethics); increasing the quality of dying and the satisfaction of skillful accompanying in dying that a priest may experience.

\section{Conclusions}

Responding to the two research questions posed at the beginning of this study, it can be said that contemporary attitudes towards death are changing, due to the increasing 
push to humanize the dying process, oftentimes through the help of teachers of dying, who utilize physical communication and listening as resources that ease their patients' confrontations with death. People today are finally experiencing the humanizing of death, which we call sharing death (Janiak 2019a, 2019b). We define the term sharing death from two perspectives. First, from the perspective of a researcher in pedagogy, by sharing death we consider the appearance in the social space of many group activities relating to dying, accompanying and mourning, which perform functions focused on:

a. help - to the terminally ill, the elderly, the dying, the caregivers and the mourners Compassionate Communities, Death Midwifery, Death Doula.

b. education - how to accompany the dying: Seven tips for cooking for the bereaved, Modern Loss, Winston Wish.

There are social actions, initiatives which fulfill the function of changing general awareness by improving social communication-giving people social communication tools effective and helpful in keeping contact with the dying and the mourning such as e.g.,: D2KDay (Dying To Know Day); TalkDeath.com; Death Café; Death Over Dinner. Educational activity is related to the importance of having accompaniment in dying, the awareness of the needs of the dying and the mourning, and the ways in which they may be satisfied, the patterns of behavior in the face of death.

Social actions and initiatives which promote social interest and are designed to facilitate social interaction: the extension of the labour market, bridging the gap (careers in death), making testaments of will, five wishes and aging with dignity, end-of-life decisions, End-of-Life University, donating our body, funeral pre-planning, green funeral trends like: water cremation (aquamation); greener flame cremation; body and tissue donation facilitation. In preparation of dying, there is a potentially important new form of community-based caregiving that may help those in need: end-of-life doulas (Krawczyk and Rush 2020). This new phenomenon, alongside the above-mentioned social initiatives, seeks to ensure that the wishes of the dead and dying are honoured (both spiritual and practical) and that conversations surrounding these topics are normalised (Jacobsen 2021).

The second perspective, as a researcher in cultural studies, find that by sharing death we understand such an attitude towards dying, which can be called, as Tony Walter (1996b, 2017) described it, living with the dying, taking into account and meeting the individual wishes of the dying and of the mourners. The animators and the promoters of this attitude are our teachers of dying.

So the term, the phrase sharing death has thus got a double meaning: It means the desire to accompany the dying and the mourning, on their terms, focusing on meeting their individual needs and being opened to death education — educational readiness, willingness to learn how to do it. This desire arises or is likely to implemented thanks to the appearance of the teachers of death.

It is also worth underscoring that contemporary teachers of death are recognized as those who publicly accompany the dying or terminally ill, promoting and (re) defining ars moriendi. Through the autoethnographic method, the authors identified three stages of the process (experience, reflection, commitment), situational factors, personality pattern and social competencies (such as openness to a meeting, accompanying, listening, communicating by touch) necessary to achieve the status of a death teacher. In addition to their social application, the activities of such people as Elisabeth Kübler-Ross, Bronnie Ware, Atul Gawande, Kathryn Mannix, Agnieszka Kaluga, Rev. Jan Kaczkowski, are also valuable in educating and contributing to the contemporary phenomenon of humanizing the experience of death (Neumann 2016; Butler 2019). The authors' research backgroundone, a cultural expert and the other a pedagogue-allowed them to identify emerging social and cultural phenomena related to attitudes towards death through the use of an autoethnographic strategy, in which their experiences became a way of understanding the social world of people confronted with death and "a tool for analyzing the relationship between their experiences and broader social structures and processes" (Aull Davies 1999, p. 185), such as the humanization of death or the attitude of shared death, and the figure 
of the death teacher. In our case, we found that autoethnography is a practical tool for changing the world. Reconstructing the figure of the teacher of dying has a dual social application intended by the authors: first, to encourage priests to take advantage of the education they offer, learn to accompany, listen and respond to the needs of the dying and mourners. Second, it is to embolden ourselves, to blunt the edge of the fear of death. It seems that when we find ourselves in need, we can easily find in our surroundings someone who is willing to teach and may even share in our experience. Just like we shared our friend Kasia's dying experience.

\section{Limitation}

This study, conducted as a qualitative paradigm, refers to the assumptions of social constructivism. Utilising this kind of paradigm, there is no 'ultimate truth' to be gleaned from the researched phenomenon. The study results are specific in nature and cannot be used to generalise about a whole population, nor are they representative of society (Shenton 2004). The knowledge obtained refers solely to teachers of dying and their role in society and cannot be divorced from its context.

Author Contributions: Conceptualization, A.J. and M.G.; methodology, A.J.; writing-original draft preparation, A.J.; writing-review and editing, M.G. All authors have read and agreed to the published version of the manuscript.

Funding: The research received no external funding.

Institutional Review Board Statement: Not applicable.

Informed Consent Statement: Not applicable.

Conflicts of Interest: The authors declare no conflict of interest.

\section{References}

Anderson, Leon. 2006. Analytic Autoethnography. Journal of Contemporary Ethnography 35: 373-95. [CrossRef]

Archer, Margaret S. 2000. Being Human: The Problem of Agency. Cambridge: Cambridge University Press.

Aries, Philippe. 1974. Western Attitudes toward Death: From the Middle Ages to the Present. Translated by Patricia M. Ranum. Baltimore: Johns Hopkins University Press.

Aull Davies, Charlott. 1999. Reflexive Ethnography. A Guide to Research Selves and Others. London: Routledge.

Butler, Katy. 2019. The Art of Dying Well: A Practical Guide to a Good End of Life. New York: Scribner.

Campesino, Maureen, and Gary E. Schwartz. 2006. Spirituality among Latinas/os: Implications of culture in conceptualization and measurement. ANS. Advances in Nursing Science 29: 69-81. [CrossRef] [PubMed]

Conrad, Peter, and Joseph W. Schneider. 1992. Deviance and Medicalization. From Badness to Sickness. Philadelphia: Temple University Press.

Curtin, Adrian. 2019. Death in Modern Theatre: Stages of Mortality. Manchester: Manchester University Press.

de Walden-Gałuszko, Krystyna. 2011. O nowych możliwościach pomocy chorym w zaawansowanym stadium choroby w świetle założeń psychologii pozytywnej. Medycyna Paliatywna 4: 197-201.

Ellingson, Laura, and Carolyn Ellis. 2008. Autoethnography as Constructionist Project. In Handbook of Constructionist Research. Edited by James A. Holstein and Jaber F. Gubrium. New York: Guilford Press.

Ellis, Carolyn. 2004. The Ethnographic I: A Methodological Novel About Autoethnography. Walnut Creek: AltaMira Press.

Gawande, Atul. 2014. Being Mortal: Medicine and What Matters in the End. New York: Profile Books Ltd.

Jacobsen, Michael Hviid. 2021. Contemplating a career in death and dying-An interview with Tony Walter. Mortality, 1-26. [CrossRef] Janiak, Agnieszka. 2019a. Sztuka Wspóbycia. Komunikacja osób Duchownych z Chorym, Umierajacym i żałobnikiem. Poznań: Pallotinum.

Janiak, Agnieszka. 2019b. Sharing Death as a New Thanatic Attitude. Contemporary Activity, Social Education and Communication to Accompany the Dying and the Mourning. In Sharing Society. The Impact of Collaborative Collective Actions in the Transformation of Contemporary Societies. Edited by Benjamín Tejerina, Cristina Miranda de Almeida and Ignacia Perugorría. País Vasco: Universidad del País Vasco.

Jankelevitch, Vladimir. 1993. Tajemnica śmierci i zjawisko śmierci. In Antropologia śmierci. Myśl. Translated by Stanisław Cichowicz, and Jakub M. Godzimirski. Myśl francuska: Wydawnictwo Naukowe PWN.

Kacperczyk, Anna. 2014. Autoetnografia-technika, metoda, nowy paradygmat? O metodologicznym statusie autoetnografii [Autoethnography-technique, method, new paradigm? On the methodological status of autoethnography. PSJ 10: 32-75.

Kafar, Marcin. 2010. O przełomie autoetnograficznym w humanistyce. W stronę nowego fparadygmatu [On the autoethnographic breakthrough in humanities. Towards a new paradigm]. In Doświadczenie Choroby w Perspektywie Badań Interdyscyplinarnych. Edited by Bożena Płonka-Syroka and Michał Skrzypek. Wrocław: Akademia Medyczna im. Piastów Śląskich. 
Kaluga, Agnieszka. 2014. Zorkownia. Kraków: Znak.

Kilpatrick, William Kirk. 1997. Psychologiczne Uwiedzenie. Translated by Radosław Lewandowski. Poznań: Wydawnictwo „W drodze. First published 1983.

Krakowiak, Piotr, and Anna Janowicz. 2012. Nowe propozycje opieki ze strony zespołowego duszpasterstwa służby zdrowia i pomocy społecznej. Pielegniarstwo i Zdrowie Publiczne 2: 153-59.

Krawczyk, Marian, and Merilynne Rush. 2020. Describing the end-of-life doula role and practices of care: Perspectives from four countries. Palliative Care \& Social Practice 14: 1-15. [CrossRef]

Kubiak, Anna E. 2014. Inne śmierci. Antropologia Umierania i żałoby w Późnej Nowoczesności. Kraków: Universitas.

Kübler-Ross, Elisabeth. 2000. Koło życia: Autobiografia. [The Circle of Life: Autobiography]. Translated by Jerzy Korpanty. Warsaw: Świat Książki. First published 1997.

Kübler-Ross, Elisabeth. 1969. On Death and Dying. New York: Simon \& Schuster.

Łuczak, Jacek. 2010. Czego może oczekiwać od kapelana szpitalnego lekarz. In Kapelan Szpitalny i Zespotfy Medyczne We Wspólnej Posłudze Przy Chorym. Conference in Łagiewniki records: March 14 2009. Kraków: Medycyna Praktyczna.

Machinek, Mariana. 2003. Czy umieranie jest sztuką? O chrześcijańskiej ars moriendi, w: Śmierć i wiara w życie pośmiertne świetle nauk przyrodniczych i humanistycznych. In Śmierć $i$ Wiara w życie Pośmiertne świetle Nauk Przyrodniczych i Humanistycznych. Edited by Mariana Machinek. Rome: Biblioteka Wydziału Teologii, pp. 241-55.

Machinek, Mariana. 2009. Towarzyszyć w ostatniej drodze. "Metoda asystowania umierającym" ks. Jana Berthier a współczesna troska o umierajacych [Accompany you on the last journey. "The method of assisting the dying", Fr. Jana Berthier and contemporary care for the dying]. "Cor unum et anima una". In Księga Jubileuszowa ku czci Księdza Jana Berthier Założyciela Zgromadzenia Misjonarzy Świętej Rodziny z okazji 100-lecia Jego śmierci. Edited by Adam Józef Sobczyk. Pelplin: Wydawnictwo Bernardinum, pp. 60-92.

Mannix, Kathryn. 2018. With the End in Mind: Dying, Death, and Wisdom in an Age of Denial, 1st ed. New York: Little, Brown Spark.

Neumann, Ann. 2016. The Good Death. An Exploration of Dying in America. Boston: Beacon Press.

Nussbaum, Martha. 2016. Nie dla Zysku. Dlaczego Demokracja Potrzebuje Humanistów. Translated by Łukasz Pawłowski. Warsaw: Fundacja Kultura Liberalna.

O'donnell, Joseph. 1982. Spirituality: A Roman Catholic Perspective. Review E Expositor 79: 293-305. [CrossRef]

Pargament, Kenneth I., and Annette Mahoney. 2012. Spirituality: The search for the sacred. In Oxford Handbook of Positive Psychology. Edited by Shane J. Lopez and C. R. Snyder. Oxford: Oxford University Press, pp. 611-19.

Piwowarski, Władysław. 1977. Religia Miejska w Rejonie Uprzemysłowionym. Studium Socjologiczne. Warsaw: Biblioteka Więzi.

Redrado, José Luis. 2010. Posługa duszpasterska w palcówkach służby zdrowia [Pastoral service in health care facilities]. In Kapelan Szpitalny i Zespoły Medyczne We Wspólnej Postudze Przy Chorym. Conference Records, Łagiewniki, 14 March 2009. Kraków: Medycyna Praktyczna.

Richardson, Laurel. 2000. Evaluating Ethnography. Qualitative Inquiry 6: 253-55. [CrossRef]

Rys, Grzegorz. 2010. W poszukiwaniu przyszłych kapelanów szpitalnych. Formacja w polskich seminariach duchownychRekonesans. In Kapelan Szpitalny i Zespoły Medyczne We Wspólnej Postudze Przy Chorym. Conference in Łagiewniki Records: 14 March 2009. Kraków: Medycyna Praktyczna, pp. 95-96.

Shenton, Andrew K. 2004. Strategies for ensuring trustworthiness in qualitative research project. Education for Information 22: 63-75. [CrossRef]

Szałata, Kazimierz. 2010. Z filozofii relacji osobowych w medycynie. Humanizacja działań medycznych a obecność kapelana przy chorym. [From the philosophy of personal relations in medicine. Humanization of medical activities and the presence of a chaplain next to a sick person]. In Kapelan Szpitalny i Zespoły Medyczne We Wspólnej Postudze Przy Chorym. Conference in Łagiewniki Records: 14 March 2009. Kraków: Medycyna Praktyczna, p. 37.

Szczepaniak, Lucjan. 2010. Posługa kapelana wśród chorych dzieci. In Kapelan Szpitalny i Zespoły Medyczne We Wspólnej Postudze Przy Chorym. Conference in Łagiewniki Records: 14 March 2009. Kraków: Medycyna Praktyczna, p. 73.

Walter, Tony. 1992. Sociologists never die: British sociology and death. The Sociological Review 40: 264-95. [CrossRef]

Walter, Tony. 1996a. A New Model of Grief: Bereavement and Biography. Mortality 1: 7-24. [CrossRef]

Walter, Tony. 1996b. Facing Death without Tradition. In Contemporary Issues in the Sociology of Death, Dying and Disposal. Edited by Glennys Howarth and Peter Jupp. London: McMillan Press Ltd., pp. 193-204.

Walter, Tony. 2017. What Death Means Now. Thinking Critically about Dying and Grieving. Boston: Police Press.

Ware, Bronnie. 2016a. Czego Najbardziej żałuja Umierajacy. Translated by Magdalena Słysz. Warsaw: Czarna Owca.

Witkowski, Lech. 2011. Historie Autorytetu Wobec Kultury i Edukacji. Kraków: Impuls.

Woodward, Kath, and Sophie Woodward. 2020. Birth and Death: Experience, Ethics, Politics. London and New York: Routledge.

Yinger, John Milton. 1957. Religion, Society, and the Individual: An Introduction to the Sociology of Religion. New York: Springer Publications.

Zinnbauer, Brian J., and Kenneth I. Pargament. 2005. Religiousness and spirituality. In Handbook of the Psychology of Religion and Spirituality. Edited by Raymond F. Paloutzian and Crystal L. Park. New York: Guilford, pp. 21-42. 